\title{
PENINGKATAN MUTU DAN KUANTITAS PRODUKSI GERABAH PADA INDUSTRI PEMBUATAN GERABAH DI MALANG JAWA TIMUR
}

\author{
Mochamad Arif Irfa'i \\ Teknik Mesin, Fakultas Teknik, Universitas Negeri Surabaya, E-mail: $\underline{\text { arifirfai@ unesa.ac.id }}$ \\ Nova Kristiana \\ Desain, Fakultas Bahasa dan Seni, Universitas Negeri Surabaya
}

Muchlis Arif

Seni Rupa, Fakultas Bahasa dan Seni, Universitas Negeri Surabaya

Tri Sudarwanto

Pendidikan Ekonomi, Fakultas Ekonomi, Universitas Negeri Surabaya

Tujuan dari kegiatan ini adalah penerapan tungku pembakaran dan pelatihan desain motif gerabah untuk membantu meningkatkan kualitas dan kuantitas produk gerabah. Metoda pelaksanaan kegiatan ini adalah tim pelaksana menganalisa permasalahan tim mitra (Bapak Suhartoko). Hasil analisa diketahui bahwa usaha gerabah Bapak Suhartoko masih menggunakan tungku pembakaran berbahan bakar kayu, kemampun mendesain motif gerabah (teknik pengglasiran) yang kurang berkembang serta manajemen pemasaran yang belum dikelola secara optimal. Berdasarkan hasil diskusi dan permintaan tim mitra, maka dilakukan perancangan untuk pembuatan tungku pembakaran sistem terkontrol, persiapan pelatihan mendesain motif gerabah (teknik pengglasiran) serta workshop pemasaran. Tahap selanjutnya dilakukan uji coba tungku pembakaran sistem terkontrol, pelatihan mendesain motif dekorasi gerabah serta workshop pemasaran. Pada akhir kegiatan dilakukan pendampingan dan evaluasi program Kemitraan masyarakat. Hasil dari kegiatan Program Kemitraan Masyarakat adalah terjadi peningkatan kualitas dan kuantitas produk gerabah setelah menggunakan tungku pembakaran sistem terkontrol. Pada saat masih menggunakan tungku manual, gerabah yang dihasilkan hanya terbuat dari tanah liat setelah menggunakan tungku pembakaran sistem terkontrol gerabah yang dihasilkan mampu menghasilkan gerabah yang terbuat dari keramik. Secara kuantitas, terjadi peningkatan produksi gerabah yang semula 8-10 buah gerabah setiap kali pembakaran menjadi 22-24 buah gerabah. Sedangkan, dari sisi desain motif gerabah sudah mulai berkembang dan mampu jual tinggi. Indikatornya harga jual produk gerabah yang meningkat dari 10 ribu rupiah sampai 15 ribu rupiah setiap produk gerabah menjadi 100 ribu rupiah sampai 150 ribu rupiah untuk setiap produk gerabah. Pada saat ini, pemasaran produk gerabah juga sudah mulai menembus gallery, hotel dan café.

Kata Kunci: tungku pembakaran; teknik pengglasiran dan pemasaran.

Abstract

The aims of this activity is the application of furnace and pottery design training to help improve the quality and quantity pottery products. The methods of implementing this activity is the implementation team analyzes the problems of the partner team (Mr. Suhartoko). The results of the analysis revealed that Mr. Suhartoko's pottery business still used wood-burning stoves, ability to design pottery motifs (grading techniques) that are underdeveloped and marketing management that has not been managed optimally. Based on the results of discussions and request of partner teams. Then the design is carried out for the manufacture of controlled system furnaces. Training preparation to design pottery motifs (grading techniques) and marketing workshops. At the end of the activity the community partnership program was facilitated and evaluated. The results of the community partnership program activities are an increase in the quality of pottery products after using a controlled furnace system. While still using the manual furnace, the pottery produced is only made of clay after using a controlled furnace system. The pottery produced is capable of producing pottery made of ceramics. In quantity, there was an increase in the production of pottery, which were from 8-10 pottery each time it processed to 22-24 pottery. While, in terms of design, pottery motifs have started to develop and are able to selling high. The indicator is that the selling price of pottery products increases from 10 thousand rupiahs to 15 thousand rupiahs for each pottery product to 100 thousand rupiahs to 150 thousand rupiahs for each pottery product. At this time, Pottery product marketing has also begun to penetrate the gallery, hotel and café.

Keywords: furnace; grading techniques and marketing. 


\section{PENDAHULUAN}

Salah satu industri kerajinan yang cukup berkembang di Kota Malang adalah industri kerajinan gerabah. Bethek dan Dinoyo merupakan daerah yang dikenal sebagai pusat sentra industri pembuatan gerabah dengan bahan baku dari tanah liat. Kedua daerah tersebut banyak ditemukan home industry pembuat gerabah. Bahkan produk-produk gerabah dari kedua daerah tersebut sudah dikenal sampai Thailand dan China. Namun kondisinya sekarang terbalik, produk-produk gerabah (keramik) dari Negara Thailand dan China banyak membanjiri pasaran gerabah di Malang dan sekitarnya. Akibatnya produk-produk lokal kalah bersaing dengan produk-produk dari Negara Thailand dan China. Sementara itu, produk-produk lokal yang dihasilkan dari industri kerajinan gerabah berupa vas atau pot bunga dan barang-barang kerajinan lainnya masih dilakukan dengan teknologi yang sangat sederhana, sentuhan seni yang masih kurang serta manajemen pemasaran yang belum dikelola secara baik sehingga produk-produk lokal kalah bersaing dengan produk dari luar negeri.

Kendala yang paling dominan adalah masalah teknologi produksi yang digunakan masih menggunakan tungku/kompor dengan bahan bakar kayu. Penggunaan tungku/kompor berbahan bakar kayu pada proses pembakaran gerabah menyebabkan kualitas hasil produksi kurang maksimal serta menimbulkan persoalan sendiri pada asap yang ditimbulkan. Asap yang ditimbulkan pada hasil sisa pembakaran menyebabkan polusi udara serta mengganggu kenyamanan lingkungan sekitar. Selain itu, penggunaan tungku/kompor berbahan bakar kayu pada proses pembakaran gerabah menyebabkan panas yang dihasilkan menjadi tidak optimal dan tidak merata. Padahal pada proses pembakaran gerabah diperlukan panas yang tinggi dan merata.

Kemampuan dalam mendesain motif dekorasi gerabah yang masih rendah menjadi permasalahan serius berikutnya bagi para pengusaha kecil pembuat gerabah, khususnya kemampuan pengglasiran. Selama ini, kemampuan mendesain motif dekorasi gerabah dari para pengusaha didapatkan secara turun temurun sehingga motif dekorasi gerabah yang ada sekarang ini cenderung monoton. Pengetahuan mengenai manajemen pemasaran menjadi kendala berikutnya yang menyebabkan usaha gerabah milik Bapak Suhartoko tidak berkembang. Padahal manajemen pemasaran yang dilakukan industri lainnya sudah menggunakan berbagai media sosial untuk urusan pemasaran. Selain itu, motif dekorasi gerabah yang ada di pasaran sudah berkembang pesat sehingga gerabah hasil produksi milik Bapak Suhartoko kalah bersaing dengan produk dari luar negeri. Teknologi produksi yang digunakan pada pembuatan gerabah masih manual, kemampuan mendesain motif dekorasi gerabah masih rendah serta minimnya pengetahun mengenai cara memasarkan suatu produk menyebabkan produk yang dihasilkan tidak maksimal dan omzet penjualan yang tidak meningkat. Kendala-kendala yang dihadapi selama proses produksi pembuatan gerabah pada usaha milik Bapak Suhartoko menyebabkan usaha pembuatan gerabah tidak mampu berkerja dengan kualitas dan waktu penyelesaian yang optimal(Soejono S., 2008). Oleh karena itu, dibutuhkan tungku pembakaran sistem terkontrol, pelatihan mendesain motif dekorasi gerabah serta workshop manajemen pemasaran supaya dapat meningkatkan produktifitas dan kualitas sesuai harapan konsumen serta peningkatan omzet penjualan.

Berdasarkan permasalahan-permasalahan yang dihadapi mitra kegiatan Program Kegiatan Masyarakat, maka perlu dicarikan solusi guna membantu permasalahan-permasalahan yang dihadapi mitra. Selain itu, kegiatan Program Kemitraan Masyarakat ini merupakan wujud salah satu Dharma pada Tri Dharma Perguruan Tinggi.

\section{METODE}

Berdasarkan informasi dari salah satu anggota tim pelaksana Program Kemitraan Masyarakat mengenai permasalahan yang dihadapi mitra ditindak lanjuti dengan kunjungan tim pelaksana ke mitra. Dari hasil kunjungan diketahui bahwa mitra memiliki permasalahan pada bidang produksi, kemampuan karyawan dalam hal mendesain bentuk dan motif gerabah yang masih rendah serta kesulitan dalam hal pemasaran produk gerabah. Permasalahan pada bidang produksi yang teridentifikasi adalah tungku yang digunakan untuk membakar gerabah masih menggunakan bahan bakar kayu, kapasitas tungku yang digunakan untuk pembakaran gerabah tidak bisa menampung banyak, waktu yang diperlukan untuk pembakaran gerabah sangat lama, asap/debu hasil pembakaran gerabah dengan menggunakan kayu menimbulkan polusi udara menyebabkan kenyamanan karyawan dalam proses produksi terganggu serta panas yang dihasilkan tungku berbahan bakar kayu tidak optimal dan tidak merata sehingga proses pembakaran gerabah dilakukan secara berulang kali. Sedangkan pada bidang desain motif gerabah, permasalahan yang teridentifikasi adalah desain motif gerabah yang dihasilkan cenderung monoton dan tidak mengikuti perkembangan motif gerabah yang sedang berkembang sehingga kurang diminati pembeli. Pada bidang pemasaran, permasalah yang teridentifikasi 
adalah minimnya kemampuan para karyawan dalam hal pemasaran produk gerabah. Selama ini, pemasaran produk gerabah hanya mengandalkan pembelian dari pedagang besar (tengkulak) yang membeli gerabah dengan harga rendah. Selanjutnya, tim pelaksana bersama mitra melakukan diskusi untuk mencari solusi terhadap permasalahanpermaslahan mitra.

Hasil diskusi antara tim pelaksana dengan mitra pada bidang produksi menyepakati untuk merancang dan membuat tungku pembakaran sistem terkontrol. Pada bidang desain motif gerabah, tim pelaksana dan mitra melakukan diskusi untuk menentukan pelatihan yang sesuai untuk meningkatkan kemampuan karyawan dalam mendesain motif gerabah. Hasil diskusi menyepakati dilakukan pelatihan pengglasiran. Mitra juga memberi masukan ke tim pelaksana untuk materi pengglasiran mencakup kemampuan-kemampuan dalam mendesain motif gerabah seperti : membuat bentuk, memberi warna dan memberi motif pada gerabah. Sedangkan pada bidang pemasaran, hasil diskusi tim pelaksana dengan mitra adalah sepakat untuk melakukan pelatihan pemasaran produk. Berdasarkan masukan mitra, materi pelatihan pemasaran menekankan strategi pemasaran di era digital. Selanjutnya, tim pelaksana bersama mitra menyiapkan alat, bahan dan tempat yang diperlukan untuk pembuatan tungku pembakaran, pelatihan desain motif gerabah dan pelatihan pemasaran produk. Pada tahap pelaksanaan, terbagi menjadi dua hari. Pada hari pertama, dilakukan cara pengoperasian tungku pembakaran dan perawatannya . Pada hari kedua, dilaksanakan pelatihan desain motif gerabah (pengglasiran) dilanjutkan penyampaian materi tentang strategi pemasaran produk di era digital. Pada akhir pelaksanaan dilakukan evaluasi dengan membagikan angket evaluasi pelaksanaan kepada peserta pelatihan. Pasca pelatihan dilakukan pendampingan dengan tetap komunikasi dengan mitra tentang dampak yang dihasilkan pasca pelatihan.

\section{HASIL DAN PEMBAHASAN}

1. Penerapan tungku pembakaran

Pada tahap perencanaan dilakukan diskusi antara mitra dengan tim pelaksana Program Kemitraan Masyarakat. Hasil diskusi diperoleh desain rancangan tungku pembakaran gerabah sesuai kebutuhan mitra. Tim pelaksana menindaklanjuti desain rancangan tungku pembakaran dengan melakukan koordinasi untuk persiapan bahan dan peralatan yang diperlukan untuk pembuatan tungku pembakaran. Bahan yang sudah dipersiapkan sesuai kebutuhan kemudian dilakukan penyambungan rangka dan perakitan bodi tungku (Harsono $\mathrm{W}$ dan Toshie Okumura, 1981). Pada tahap akhir, dilakukan kegiatan ujicoba untuk memastikan performa atau unjuk kerja tungku pembakaran sesuai kebutuhan mitra.

Tabel 1. Spesifikasi Teknik Tungku Pembakaran

\begin{tabular}{lc}
\hline Tinggi (height) & $\mathbf{1 5 0 0 ~} \mathbf{~ m m}$ \\
\hline Lebar (width) & $900 \mathrm{~mm}$ \\
\hline Kapasitas (capacity) & $25 \mathrm{~kg}$ \\
\hline $\begin{array}{l}\text { suhu maksimum } \\
\text { (maximum temperature) }\end{array}$ & $1350^{\circ} \mathrm{C}$ \\
\hline
\end{tabular}

Penerapan tungku pembakaran pada industri pembuatan gerabah pimpinan Bapak Suhartoko sangat membantu dalam memperbaiki kualitas dan kuantitas produk gerabah. Sebelum pemberian bantuan tungku pembakaran, industri pembuatan gerabah pimpinan Bapak Suhartoko menggunakan kompor berbahan bakar kayu untuk membakar gerabah yang telah dibuat.

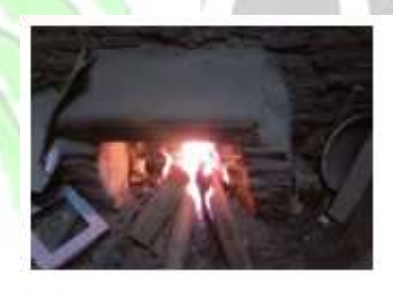

a

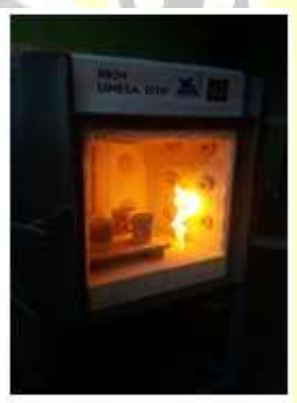

b
Gambar 1. a. kompor berbahan bakar kayu, b. tungku pembakaran yang diterapkan ke mitra

Pada penggunaaan kompor berbahan bakar kayu untuk setiap kali pembakaran gerabah mampu membakar gerabah 8 buah gerabah sedangkan pada pembakaran gerabah dengan menggunakan tungku pembakaran kapasitas yang dihasilkan 22-24 gerabah untuk setiap proses pembakaran gerabah. Temperatur maksimum yang dihasilkan dengan kompor berbahan bakar kayu adalah $400^{\circ} \mathrm{c}$, sedangkan temperatur maksimum yang mampu dihasilkan dengan menggunakan tungku pembakaran adalah $1350^{\circ} \mathrm{C}$ (J. P. Holman dan Jasjfi E., 1984). Dampak dari penggunaaan penggunaan temperatur maksimum adalah pada kualitas produk gerabah. Apabila selama ini, produk gerabah dengan menggunakan kompor berbahan bakar kayu hanya mampu bersaing di pasar tradisional. Setelah penggunaan tungku pembakaran, maka produk gerabah sudah mampu menembus pasar yang lebih 
luas, seperti: hotel, kafe dan gallery. Perbedaan produk gerabah dengan menggunakan kompor berbahan bakar kayu dengan tungku pembakaran dapat dilihat pada tabel dibawah ini:

Tabel 2. Perbedaan proses pembuatan gerabah antara kompor berbahan bakar kayu dengan tungku

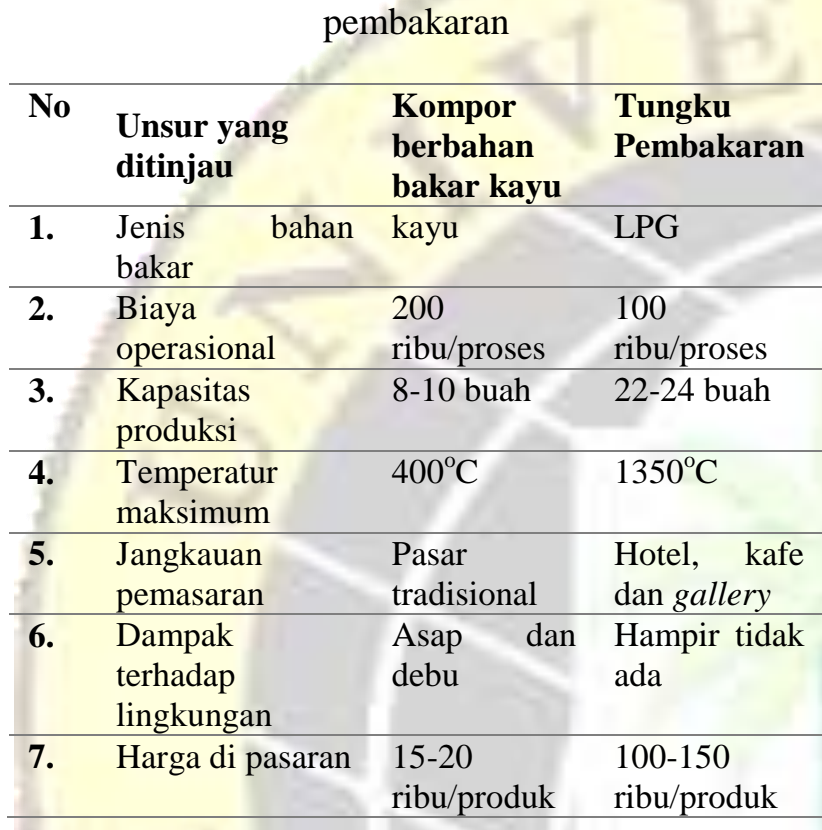

2. Hasil Pelatihan Desain Motif Gerabah

Selain pendampingan dalam penerapan tungku pembakaran, kegiatan lain yang dilakukan adalah pelatihan pengglasiran. Sebelum adanya pelatihan, produk gerabah hanya dalam bentuk pemberian motif sederhana yaitu gerabah digambar dengan menggunakan cat warna. Setelah adanya pelatihan pengglasiran, produk gerabah mulai mengenal bentuk-bentuk desain gerabah yang berkembang (up to date) saat ini seperti: bentuk motif abstrak, cetak timbul, motif bunga, motif batik dan motif-motif lainnya yang berkembang saat ini (Lip Evelyn, 2011).

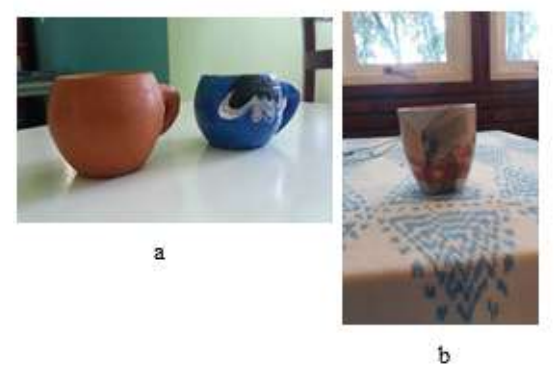

Gambar 2. a. desain motif gerabah sebelum pelatihan, b. desain motif gerabah sesudah pelatihan

Hasil dari pemberian motif pada desain gerabah juga berdampak pada harga jual. Selama ini, untuk harga jual dengan pemberian motif gerabah yang digambar dengan menggunakan cat warna dihargai 15-20 ribu/produk, sedangkan harga jual untuk gerabah dengan desain motif terkini untuk penjualan di gallery seni maupun hotel bisa menacapai 100$150 \mathrm{ribu} /$ produk.

Pemasaran yang dilakukan sebelum adanya pelatihan pemasaran melalui tengkulak (pedagang besar) yang mengambil produk dari perajin gerabah atau para perajin gerabah menitipkan gerabah untuk dijual oleh para pedagang di pasar tradisional.

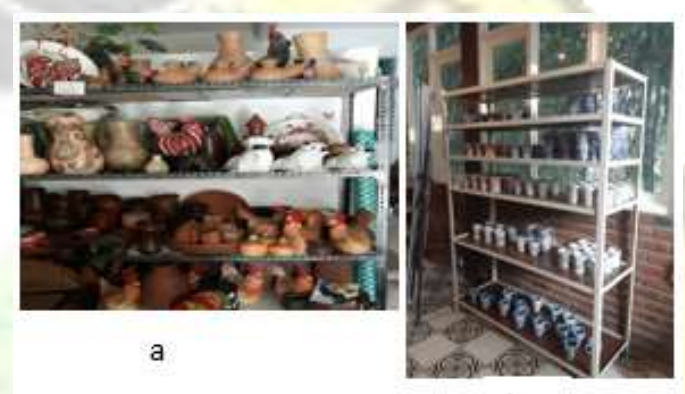

b

Gambar 3. a. penjualan gerabah pada pasar tradisional, b. salah satu display gerabah yang dijual pada gallery seni

Kelemahannya cara pemasaran semacam itu adalah harga jual dari produk gerabah menjadi murah karena para tengkulak memberi dalam jumlah besar (borongan), para perajin gerabah tidak bisa mematok harga yang tinggi karena harga sudah ditentukan oleh para pedagang besar (tengkulak) dan jangkauan pemasaran hanya terbatas pada daerah sekitar (lokal) (Gito S., 2014). Setelah para perajin menerima pelatihan pemasaran dan keuangan, terjadi dampak terhadap pemasaran produk gerabah. Pemasaran sudah dilakukan melalui media sosial seperti : facebook, whatsapp dan Instagram. Kelebihan dari pemasaran dengan menggunakan media sosial adalah jangkauan pemasaran luas, para perajin bisa menentukan harga sesuai dengan kualitas produk dan produk gerabah sudah mampu menembus hotel, cafe maupun gallery.

\section{Ucapan Terima Kasih}

Terima kasih kepada DRPM KemenristekDikti yang telah mensuport dana melalui skema Program Kemitraan Masyarakat tahun pelaksanaan 2019 serta LPPM Universitas Negeri Surabaya. Terima kasih kepada Bapak Suhartoko selaku ketua paguyuban perajin gerabah dan seluruh para perajin gerabah di Desa Bethek, Malang Jawa Timur atas kerja sama sebagai mitra dalam kegiatan Pengabdian Kepada Masyarakat. 


\section{KESIMPULAN}

Tim Program Kemitraan Masyarakat telah melaksanakan kegiatan pengabdian kepada masyarakat di Desa Bethek Malang Jawa Timur dengan sasaran perajian gerabah. Kegiatan pengabdian masyarakat yang telah dilakukan meliputi : pembuatan dan pelatihan pengoperasian tungku pembakaran, pelatihan desain motif gerabah dan pelatihan pemasaran serta pengelolaan keuangan. Dampak dari kegiatan program pengabdian kepada masyarakat terlihat dari sisi kualitas produk gerabah semakin bagus yang diindikasikan dari harga jual produk gerabah semakin meningkat, jangkauan pemasaran sudah lebih luas serta kemampuan para perajin dalam desain motif gerabah sudah semakin baik.

\section{SARAN}

Perlu dilakukan pendampingan dan evaluasi kegiatan secara berkelanjutan supaya industri pembuatan gerabah terus tumbuh dan berkembang pasca kegiatan Pengabdian Kepada Masyarakat serta mitra dapat menemukan solusi yang tepat apabila dalam kegiatan produksi gerabah menemui permasalahan terkait penerapan tungku pembakaran, desain motif maupun pemasaran.

\section{DAFTAR PUSTAKA}

Gito Sudarmo, 1994, Manajemen Pemasaran, BPFE Yogyakarta

Harsono W, Toshie Okumura, 1981, Teknologi Pengelasan Logam, Pradnya Paramita. Jakarta.

J.P Holman ( Jasjfi, E ), 1984, Perpindahan Kalor, Edisi kelima, Erlangga, Jakarta

Lip Evelyn, 2011, Desain dan Feng Shui Logo, merk dagang \& Sign Boards, PT. ELex Media Komputindo. Jakarta

Plomp, Tj, 2008, Educational Design: Introduction. From Tjeerd Plomp (eds). Educational \&Training System Design: Introduction. Design of Education and Training (in Dutch).Utrecht (the Netherlands): Lemma. Netherland. Faculty of Educational Science andTechnology, University of Twente

Soejono Soekanto, 2008, Sosiologi Industri, Remaja Karya, Bandung. 